\title{
Atıf Dizinlerindeki Türkiye Adresli Dergiler Üzerine Bir Değerlendirme
}

\author{
An Evaluation on Turkey Addressed Journals in Citation \\ Indexes
}

\author{
Umut $A L^{*}$ ve irem SOYDAL**
}

\begin{abstract}
Öz
Türkiye'de özellikle akademik camiada atıf dizinlerine çok büyük değer verilmektedir. Son yıllarda konuyla ilgili akademik çalışmaların ve popüler bilim yazılarının sayısının önemli düzeyde arttı̆̆ görülmektedir. Bununla birlikte atıf dizinleri ile ilgili yaşanılan gelişmelerin de dikkate alınması gerekmektedir. Bu alandaki önemli gelişmelerden birisi atıf dizinlerinin ticari sahibi konumunda bulunan kuruluşun almış olduğu genişleme kararıdır. Bu kararla birlikte aralarında Türkiye'nin de bulunduğu pek çok ülkeden çok sayıda dergi atıf dizinleri kapsamına alınmıştır. Söz konusu genişleme kararının sadece dünyadaki dergi sayısındaki artış ile açıklanması mümkün değildir. Atıf dizinlerine rakip olarak piyasada yer alan bazı oluşumların (Google Scholar, Scopus gibi) ve kuruluşun pazar payını artırma amaçı olarak veri tabanını sattığı ülkelerdeki dergilere daha fazlayervermesinin bu kararın alınmasında etkiliolduğu düşünülmektedir. Böyle bir ortamda Türkiye'nin kendi dergilerini değerlendirerek, atıf dizinlerine yeni dâhil edilen dergiler arasında kendine saygın bir konum edinme yönünde çalışmalar yapması gerekmektedir. Bu çalışma ile atıf dizinlerindeki Türkiye adresli dergilerin Türkiye'nin yayın üretimindeki yeri, etki faktörü açısından alanlarında nasıl bir konuma sahip oldukları, ne derece yerel dergi niteliği gösterdikleri konuları araştırılmaktadır. Çalışmanın bulguları Türkiye adresli dergilerdeki her beş yayından dördünde en az bir yazarın Türkiye'den olduğunu ve her üç yayından birinin Türkçe olduğunu göstermektedir. Bununla birlikte atıf dizinleri kapsamındaki Türkiye adresli dergilerin yayın kurullarında ağırlıklı olarak Türkiye adresli bilim insanlarının bulunduğu saptanmıştır. Türkiye adresli dergilerin bağlı bulundukları alanlarda nispeten düşük etki faktörüne sahip dergiler arasında yer aldığı ve bunun bir noktaya kadar dergilerin taşımış olduğu yerel özellikler ile ilgili olduğu düşünülmektedir.
\end{abstract}

Anahtar sözcükler: Atıf dizinleri, Dergilerin değerlendirilmesi, Bibliyometri, Türkiye adresli dergiler

\footnotetext{
* Dr.; Hacettepe Üniversitesi Bilgi ve Belge Yönetimi Bölümü Beytepe 06800-Ankara. (umutal@hacettepe.edu.tr)

** Öğr. Gör. Dr.; Hacettepe Üniversitesi Bilgi ve Belge Yönetimi Bölümü Beytepe 06800-Ankara. (soydal@hacettepe. edu.tr)
} 


\begin{abstract}
Turkish academia places a premium on citation indexes. In recent years, there has been a significant increase in the number of related academic articles and popular scientific papers. Considering the importance of citation indexes in Turkey, recent developments on this issue should not be overlooked. One of the most important developments in this area has been the expansion decision of the company, which is the commercial owner of the citation indexes. With the expansion decision, a large number of journals from many countries including Turkey were added in the citation indexes. It is impossible to say that this decision of expansion could only be related to the increasing number of journals all around the world. Some new formations (such as Google Scholar, Scopus, etc.) that have taken place in the market as the competitors of citation indexes, and the owner company's tendency to accommodate the journals of the countries to which it sells databases in order to increase its market share, should have influenced this decision. In such an environment, Turkey needs to evaluate its own journals and try to acquire a solid place within the citation indexes. This study investigates the Turkey addressed journals included in the citation indexes in terms of their places in the production of scientific publications in Turkey, and their impact factors in the related areas. The study also aims to reveal the extent to which Turkey addressed journals in citation indexes can be accepted as domestic. The results of this study show that in Turkey addressed journals, four-fifth of papers have at least one author from Turkey, and one-third of all publications are in Turkish. In addition, it was found out that the scientists in the editorial boards of Turkey addressed journals in citation indexes are mainly from Turkey. It was also found out that, Turkey addressed journals have relatively low impact factors in the related fields, the reason of which could be attributed to the regional characteristics of Turkey addressed journals.
\end{abstract}

Keywords: Citation indexes, Evaluation of journals, Bibliometrics, Turkey addressed journals

\title{
Giriş
}

Bilim dünyasında atıf dizinlerinde yayın sahibi olmak önemli bir saygınlık göstergesi olarak kabul edilmekte, atıf dizinleri bibliyometrik analizler için önemli bir veri kaynağı işlevi görmektedir. Atıf dizinleri kapsamındaki yayınlar ve bu yayınlara yapılan atıflar çeşitli şekillerde değerlendirilmekte, kişi, kurum ya da ülke karşılaştırmalarında bu verilerden yararlanılmaktadır. Bilimsel bilgi üretimindeki artışa paralel olarak dergi sayısında da önemli düzeyde artışın gerçekleştiği bilinmektedir. Kimi zaman atıf dizinlerinin bir kalite göstergesi olarak kabul edilmesi de sıklıkla karşılaşılan bir durumdur.

Ülkemizde atıf dizinlerine karşı gösterilen ilgi her geçen yıl artmaktadır. Özellikle üniversitelerde görev yapmakta olan araştırmacılar atıf dizinleri kapsamında yayın sahibi olmayı önemsemektedir. Zaten Türkiye, atıf dizinleri kapsamındaki üniversite merkezli yayın üretiminin en yüksek olduğu ülkelerden birisidir (Moed, 2006, s. 19). Bu durumun temel nedenleri arasında atıf dizinlerinin yaygın kullanımından ötürü daha fazla kişiye ulaşabilme arzusu, belli bir kadroya atanmak için gereken ölçütlerden birini yerine getirme isteği ve akademisyenlere verilen çeşitli teşvikler önemli yer tutmaktadır. 
Bireyler açısından yayınlarının atıf dizinleri kapsamında yayımlanıyor olması ne denli önemliyse ülkeler açısından da söz konusu dizinlerde dergi sahibi olabilmek o derece önem taşıyan bir konudur. Hatta bazı yazarlar, dizinlerde taranan dergilerde makale yayımlanması kadar bu dizinlerde taranan dergi sayısının artırılmasına yönelik çalışmalar yapılmasının da önemli olduğunu özellikle vurgulamaktadır (Arıoğlu ve Girgin, 2002; Yılmaz, 2002).

Son yıllarda atıf dizinlerine giren Türkiye adresli dergi sayısında da önemli artışlar olduğu gözlenmektedir. Kanımızca bu durumun önemli nedenleri arasında Türkiye'deki dergilerin bu platforma kabul edilme isteklerinin yanı sıra atıf dizinlerini ticari olarak sunan kuruluşun mevcut yapıyı genişletme çalışmalarının da payı bulunmaktadır. Bu genişletme çabalarının bir sonucu olarak Aralık 2009 itibariyle Web of Science'da dizinlenen Türkiye adresli dergi sayısının 73 olduğu ULAKBiM (2009) tarafından belirtilmektedir.

Bu çalışmada, atıf dizinlerindeki Türkiye adresli dergilerin Türkiye'nin yayın üretimindeki yeri, etki faktörü açısından alanlarındaki konumları, söz konusu dergilerin ne derece yerel dergi niteliği gösterdiği konuları ele alınmaktadır.

\section{Önceki Çalışmalar}

Dergilerin bibliyometrik göstergeler açısından değerlendirilmesi birçok araştırmaya konu olmuştur. İlgili araştırmalar incelendiğinde etki faktörünün bir değerlendirme aracı olarak kullanıldığı çalışmalar dikkati çekmektedir (Najman ve Hewitt, 2003; Saha, Saint ve Christakis, 2003; Semenzato, Rizzato ve Agostini, 2004). Etki faktörü, bir dergide, önceki iki yılda yayımlanan makalelere o yıl içerisinde yapılan atıf sayısının, o derginin önceki iki yılda yayımladığı makale sayısına bölünmesiyle hesaplanmaktadır (Garfield, 1994).

Etki faktörü dergilerin göreceli önemine ilişkin en bilinen değerlendirme ölçütü olmakla birlikte (Rousseau, 1988, s. 249), bu ölçüte ilişkin eleştiriler de gündeme gelmektedir. Bunlar arasında etki faktörü hesaplanırken kullanılan atıf verisinin kısa bir dönemi (iki yıl) içermesi, yayın türü ayrımı, dil ve etki faktörünün ne denli temsil edici yapıya sahip olduğu gibi konular yer almaktadır (Cameron, 2005, ss. 109-110). Zaten 2007 ve 2008 yıllarına ait JCR (Journal Citation Reports)'lerde etki faktörü için beş yıllık bir atıf penceresi iki yıllık olan ile birlikte sunulmaktadır (Jacsó, 2009). Atıf dizinleri birçok farklı türdeki yayını içermesine karşın, etki faktörünün hesaplanmasında bu yayın türlerinin tamamı dikkate alınmamaktadır. Etki faktörü hesaplanırken payda kısmında atıf yapılabilir kabul edilen dokümanlara yer verilmekte, pay kısmında ise tüm doküman türlerine yapılan atıflar yer almaktadır (Dong, Moh ve Mondry, 2005). Etki faktörü hesaplamasına göre atıf yapılabilir kabul edilen doküman türleri makale, tanıtım ve notlardır. Bu durum atıf yapılabilir kabul edilen yayın türleri dışında yayınlara ağırlık veren dergilerin etki faktörlerinin daha yüksek çıkmasına yol açmaktadır (Van Leeuwen ve Moed, 2002, s. 251). 
Atıf dizinlerinde yer alan dergilerin etki faktörlerinin analiz edilmesinin yanı sıra söz konusu dergilerdeki yayınların dile, yazarların ya da yayın kurulundaki hakemlerin bağlı olduğu ülkelere göre dağılımının da incelendiği birçok çalışmaya rastlanmaktadır. Bu çalışmalarda uluslararasılık, yerellik, bölgesellik gibi kavramlara yönelik tartışmalar gerçekleştirilmektedir (Marušić ve Marušić, 1999; Tijssen, 2007; Zitt ve Bassecoulard, 1998). Atıf dizinleri daha çok Amerikan ve İngiliz kaynaklı dergileri kapsamakla birlikte yapı itibariyle uluslararası niteliğe sahiptir. Atıf dizinlerine yönelik olarak uluslararasılık kavramı daha çok bu içeriğe birlikte katkıda bulunan ve bu içerikten yararlanan ülkelerin çeşitli olması ile açıklanabilir. Oysa, bilimsel yayıncılık söz konusu olduğunda bir derginin uluslararası ya da yerel niteliğe sahip olup olmadığının göstergeleri arasında yayının dili, farklı ülkelerdeki araştırmacıların katkıları, yayın kurulundaki kişilerin kimliği gibi konular yer almaktadır. Yine de bir derginin uluslararası olup olmadığını belirlemenin zorluğu literatürde vurgulanmaktadır (Buela-Casal, Perakakis, Taylor ve Checa, 2006; Uzun, 2004). Konuya bibliyometrik açıdan bakıldığında ise yerel nitelikteki dergilerin uluslararası niteliğe sahip dergilerle karşılaştırıldığında nispeten daha düşük etkiye sahip olduğunu gösteren çalışmalar ön plana çıkmaktadır (Katz ve Hicks, 1997).

Türkiye'deki çalışmalarda ise kimi zaman dergilerin tamamı (Al, 2008; Asan, 2006), kimi zaman sadece atıf dizinleri kapsamındaki belli bir dergi (Al ve Coştur, 2007; Birinci, 2008; Orbay, Karamustafaoğlu ve Öner, 2007) incelenmiştir. Bu çalışmalarda atıf analizleri yapılmış, yıllar içinde Türkiye adresli dergilerin etki faktörlerindeki değişimler araştırılmıştır. Atıf dizinlerindeki Türkiye adresli dergilerin kapsamlı bir şekilde ele alındığı bir doktora çalışmasında (Al, 2008), 2004 yılı itibariyle $J C R$ kapsamında Türkiye adresli dört derginin bulunduğu ifade edilmektedir. 2008 yılına ait $J C R^{\prime}$ de Türkiye adresli dergi sayısı ona yükselmiştir. Turkish Journal of Chemistry'nin bibliyometrik analizinin gerçekleştirildiği çalışmalardan birinde (Birinci, 2008) en verimli yazarların hangileri olduğu, yayımlanan makalelerin bibliyometrik yasalara uyup uymadığı, atıf yapılan kaynak türleri gibi konular ele alınırken; aynı dergiye yönelik bir başka çalışma (Orbay ve diğerleri, 2007) bibliyometrik bir gösterge olan $h$-endeksi bağlamında bu dergiyi incelemektedir.

\section{Yöntem}

Araştırmamızın amacı atıf dizinleri kapsamındaki Türkiye adresli dergileri çeşitli açılardan değerlendirmek ve alanlarındaki konumlarını ortaya koymaktır. Bu bağlamda dergilerin atıf performansı da incelenmektedir. Araştırmamızda aşağıdaki sorulara yanıt aranmaktadır:

$\diamond$ Türkiye adresli dergiler atıf dizinleri kapsamındaki Türkiye'nin yayın üretimine ne düzeyde etki etmektedir?

$\diamond$ Alanlarındaki diğer dergilerle karşılaştırıldığında Türkiye adresli dergiler etki faktörü açısından nasıl bir konuma sahiptir? 
$\diamond \quad$ Atıf dizinleri kapsamındaki Türkiye adresli dergiler yerel dergi niteliğinde midir?

$\diamond$ Dergilerdeki yayınların ne kadarı Türkiye adresli yazarlar tarafından üretilmiştir?

$\diamond$ Dergilerdeki yayınların ne kadarı Türkçe'dir?

$\diamond$ Dergilerin hakem kurullarındaki kişilerin ne kadarı Türkiye adreslidir?

Çalışmamıza kaynaklık eden verileri sağlamak amacıyla atıf veri tabanları (SCl, $S S C l$ ve $A \& H C l$ ) ile $J C R$ kullanılmıştır. Atıf veri tabanlarındaki taramalar 15 Aralık 2009 tarihinde gerçekleştirilmiştir. Dergilerin etki faktörlerine yönelik analizleri yapabilmek için ise $J C R^{\prime}$ nin iki farklı sürümünün (Science Edition ve Social Sciences Edition) 19972008 yılları incelenmiştir.

Araştırmamızda Türkiye adresli dergileri etki faktörlerine göre inceleyebilmek ve gerekli karşılaştırmaları yapabilmek için ilgili alandaki tüm dergilerin etki faktörleri elde edilmiştir. Dergilerin etki faktörlerinin alandan alana farklılık gösterdiği bilindiğinden karşılaştırmalar sadece dergilerin ait oldukları alan içinde yapılmıştır.

Atıf dizinleri kapsamındaki Türkiye adresli dergileri saptamak için çeşitli taramalar gerçekleştirilmiştir. ULAKBIM (2009) web sayfasındaki 73 dergiden iki tanesinin taramanın yapıldığı tarih itibariyle atıf dizinleri kapsamında herhangi bir yayını bulunmadığı saptanmış, söz konusu iki dergi (Journal of the Faculty of Engineering and Architecture of Gazi University ve UHOD-Uluslararası Hematoloji-Onkoloji Dergisi) bu çalışmanın kapsamı dışında bırakılmıştır. Böylece çalışma kapsamında toplam 71 dergi yer almıştır. Bu dergiler arasında bir derginin (Mediterranean Journal of Otology) ad değiştirdiği, bir derginin (Energy Education Science and Technology) ise bölündüğü saptanmıştır. Ad değiştiren dergiye yönelik değerlendirme yeni adı (Journal of International Advanced Otology) altında yapılırken, bölünme olan dergi iki ayrı dergi (Energy Education Science and Technology Part A - Energy Science and Research ve Energy Education Science and Technology Part B - Social and Educational Studies) olarak incelenmiştir.

Türkiye adresli dergilerdeki yayın kurulu üyelerinden ne kadarının Türkiye'de görev yaptığı araştırılırken dergilerin web sayfalarından ve basılı kopyalarından yararlanılmıştır. Bazı dergilerde farklı tanımlamaların (yayın kurulu, danışma kurulu, hakem kurulu, yazı değerlendirme kurulu vb.) yapıldığı görülmüş, hakemlik özelliği gösteren tüm kurullar birarada değerlendirilmiştir. Hakem kuruluna yönelik herhangi bir bilginin bulunamadığı durumlarda ise sadece "editorial board" biçiminde geçen bölümde yer alan isimler dikkate alınmıştır. Bazı dergilerde araştırma sorumuzu yanıtlayacak nitelikte bilgi bulunmadığından, yayın kuruluna yönelik değerlendirmeler 68 dergi üzerinden gerçekleştirilmiştir. 


\section{Bulgular ve Yorum}

Birey bazlı değerlendirmeler atıf dizinlerinde yayın sahibi olmanın önemine dikkati çekerken, ülkeler açısından önemli olan konu atıf dizinlerine dergi sokabilmektir. Özellikle atıf dizinlerinin oluşturulmaya başlandığı yıllarda dizinlerde yer alabilmek birçok editörün önemsediği bir konu olmuştur. Öte yandan son yıllarda yaşanan yeni dergilerin dizinlere dâhil edilmesi süreci atıf dizinlerinin eskisi kadar "seçici" davranmadığının en açık göstergesidir. Ticari bir yapı olduğu bilinen ve atıf dizinlerinin üreticisi konumunda bulunan Thomson Reuters'in izlemiş olduğu genişleme politikası ile birçok yerel dergi atıf dizinlerindeki yerini almıştı. Son genişlemede atıf dizinlerine 1544 yeni yerel dergi girmiştir (Thomson Reuters, 2009)* ve önceki yıllarda bu kadar çok derginin bu kadar kısa süre içerisinde dizinlere alındığı görülmemiştir. Bu dergiler arasında $J C R^{\prime}$ nin 2008 yıIna ait Science Edition'ında 2506 ve Social Sciences Edition'nında 1060 dergisi bulunan ABD'nin sadece bir dergisinin yer alması ilginç bir nokta olarak karşımıza çıkmaktadır. Bu süreçte Avustralya 52, Almanya 50, İspanya 44, Polonya 43, Çin Halk Cumhuriyeti 34, Japonya 30 yeni dergiyi atıf dizinlerine sokmuştur (Thomson Reuters, 2009).

Türkiye'nin atıf dizinleri kapsamındaki ilk dergisi Hacettepe Bulletin of Social Sciences and Humanities adlı dergidir. Söz konusu dergide 1970-1972 yılları arasında yayımlanan çalışmalar SSCl'deki yerini almış, 1973 yılından itibaren taranması durdurulmuştur. Türkiye adresli başka bir derginin atıf dizinlerine girmesi için ise 12 yıllık bir süre geçmiş, Turkish Journal of Pediatrics 1984 yılı itibariyle SCl'deki yerini almıştır. Şekil 1'de yıl yıl Türkiye adresli olarak kaç derginin atıf dizinlerince tarandığı bilgisi verilmektedir.

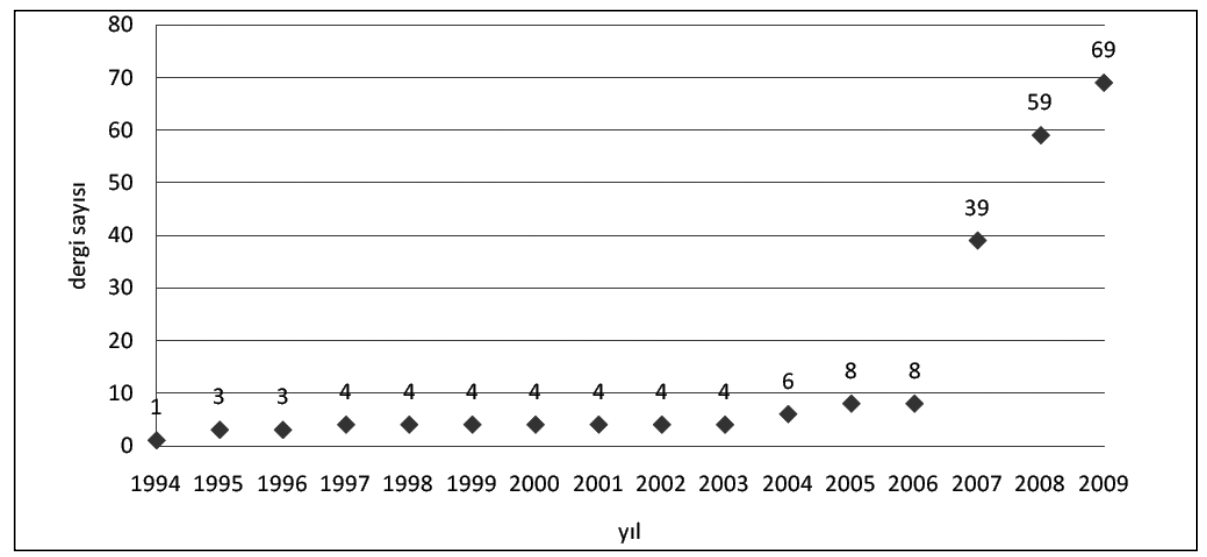

Şekil 1. Yıllara Göre Atıf Dizinlerindeki Türkiye Adresli Dergi Sayıları

Turkish Journal of Pediatrics 1984-1994 yılları arasında atıf dizinlerindeki tek Türkiye adresli dergi olma özelliğini göstermiştir. 1995-1996 yıllarında iki dergi (Turkish Journal of Chemistry ve Türk Psikoloji Dergisi) daha dizinlere dâhil edilmiştir. 1997 yılında ise Turkish

* Thomson Reuters (2010) bu sayının 2010 yılında 1620'ye ulaştığını rapor etmiştir. 
Journal of Veterinary \& Animal Sciences adlı dergi atıf dizinlerindeki yerini almıştır. Türkiye adresli dergiler olarak bu dört dergi 2004 yılına kadar Türkiye'yi atıf dizinlerinde temsil etmiştir. Atıf dizinleri kapsamındaki Türkiye adresli dergi sayısının 2004 yılında altı, 2005 ve 2006 yıllarında ise sekiz olduğu saptanmıştır (Bkz. Şekil 1). Atıf dizinlerindeki Türkiye adresli dergi sayısı Thomson Reuters'in yeni politikası ile birlikte 2007 yılında 39'a, 2008 yılında ise 59'a ulaşmıştır. Bu çalışmaya yönelik olarak taramayı gerçekleştirdiğimiz tarih itibariyle, atıf dizinleri kapsamındaki Türkiye adresli dergi sayısı 69'dur. Atıf dizinlerinde yer aldığı bilinen Journal of the Faculty of Engineering and Architecture of Gazi University, UHOD-Uluslararası Hematoloji-Onkoloji Dergisi, Tarım Bilimleri Dergisi ve TUBA-AR-Turkish Academy of Sciences Journal of Archaeology adlı dergilere ilişkin dizinleme işlemleri tamamlanmadığından bunlara ait herhangi bir kayda erişim sağlanamamıştır. Bu nedenle Şekil 1'de 2009 yılına ait dergi sayısı 69 olarak verilmektedir.

Dergi sayısındaki hızlı artış dikkate alındığında, yakın zamanda atıf dizinlerinde yer alan Türkiye adresli dergi sayısının 100'ü geçeceği düşünülmektedir. Daha önceleri göreceli olarak kalite göstergesi olduğu varsayılan atıf dizinlerine bu kadar kısa sürede bu denli çok sayıda derginin alınmasının hangi faktörlerden etkilendiği ve ne derece dergilerin kalitesi ile ilgili olduğu düşünülmelidir. Bu durum uygulanacak politikalarda (yayın teşvikleri, akademik yükselme ölçütleri vb.) yakın gelecekte birtakım değişiklikleri zorunlu kılacaktır.

\section{Türkiye Adresli Dergilerin Türkiye'nin Yayın Üretimine Etkisi}

Dergi sayısındaki artış hiç şüphesiz atıf dizinleri kapsamında yapılan Türkiye adresli yayın sayısını da etkilemektedir. Bu etkinin ne düzeyde olduğunu görebilmek amacıyla Türkiye adresli toplam yayının ne kadarının Türkiye adresli dergilerden geldiği incelenmiştir. Buna göre, 2007 yılına kadar Türkiye adresli dergilerin Türkiye'nin yayın üretimine katkısı dalgalı bir seyir izlerken, 2007 yılı itibariyle önce yüzde 7'nin üzerine, sonraki yıllarda da yüzde 10'un üzerine çıktığı görülmektedir (Bkz. Şekil 2).

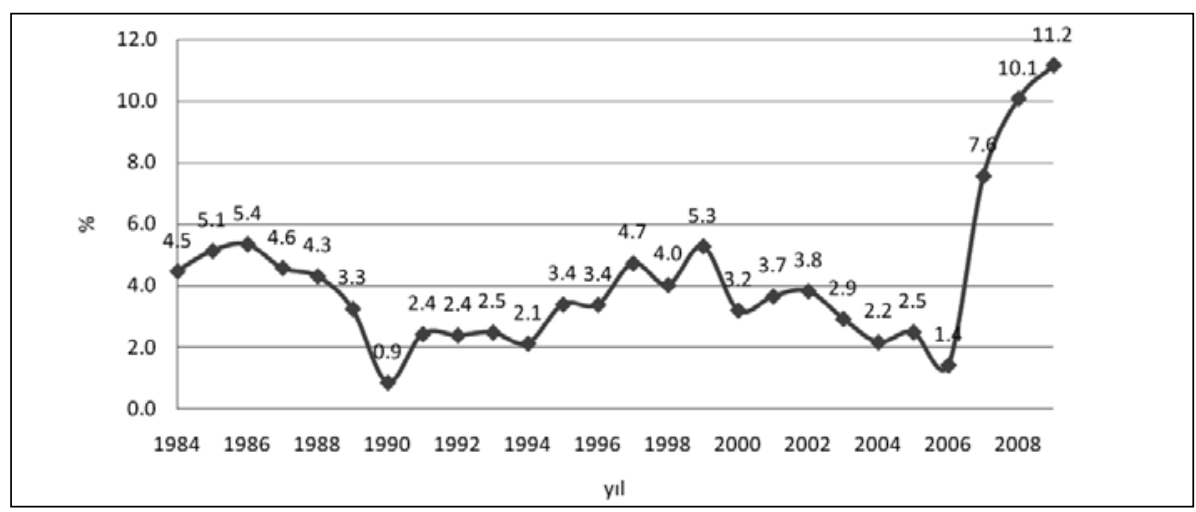

Şekil 2. Türkiye Adresli Dergilerin Türkiye Adresli Yayın Üretimindeki Payı 
Özellikle 1980'li yılların ortalarından başlayarak Türkiye'deki araştırmacıların atıf dizinleri kapsamında yayın yapmaya çalıştıkları bilinmektedir. Birtakım teşviklerin de gündeme gelmesiyle Türkiye adresli yayın sayısı her geçen yıl belli miktarda artış göstermiştir. Yapılan tarama sonucunda 1966-2009 yılları arasında Türkiye adresli yayın sayısının 194.213 olduğu, bu yayınların 10.030'ununTürkiye adreslidergilerde yayımlandığı saptanmıştır. Bu veriler söz konusu döneme ait Türkiye adresli yayın üretiminde \%5'lik bölümün Türkiye'deki dergilerden geldiğini ortaya koymaktadır. Bu dergiler arasında en fazla Türkiye adresli yayın ile katkıda bulunan on dergi Tablo I'de sunulmaktadır.

Tablo I. Türkiye Adresli Araştırmacıların En Sık Yayın Yaptığı Türkiye Adresli Dergiler

\begin{tabular}{lc}
\hline Dergi adı & Yayın sayısı \\
\hline Turkish Journal of Veterinary \& Animal Sciences & 1603 \\
Turkish Journal of Pediatrics & 1568 \\
Turkish Journal of Chemistry & 721 \\
Türkiye Klinikleri Tıp Bilimleri Dergisi & 546 \\
Anadolu Kardiyoloji Dergisi & 463 \\
Turkish Journal of Medical Sciences & 264 \\
Mikrobiyoloji Bulteni & 260 \\
Turkish Neurosurgery & 199 \\
Ulusal Travma ve Acil Cerrahi Dergisi & 193 \\
Kafkas Üniversitesi Veteriner Fakültesi Dergisi & 189 \\
\hline
\end{tabular}

Uzun yıllardır atıf dizinlerinde bulunan Turkish Journal of Veterinary \& Animal Sciences, Turkish Journal of Pediatrics ve Turkish Journal of Chemistry doğal olarak en sık yayın yapılan dergiler sıralamalarında başta yer almaktadır. Bununla birlikte 2007 yılında dizinlere dâhil olmasına karşın kısa sürede çok sayıda yayın üreten dergilerin (Türkiye Klinikleri Tıp Bilimleri Dergisi, Anadolu Kardiyoloji Dergisi, Kafkas Üniversitesi Veteriner Fakültesi Dergisi, Turkish Journal of Medical Sciences* gibi) bu sıralamaları değiştireceği düşünülmektedir.

\section{Dergilerin Etki Faktörlerine Yönelik Değerlendirme}

Dergilerin etki faktörlerine yönelik karşılaştırmalarda JCR adlı kaynaktan yararlanılmaktadır. Çalışmanın yapıldığı tarih itibariyle erişilebilen en son JCR 2008 yılına ait olandır. 2008 yılı itibariyle $J C R^{\prime}$ de yer alan Türkiye adresli dergi sayısı 10'dur. Bu dergilerin etki faktörleri bakımından alanlardaki konumu Tablo Il'de gösterilmektedir.

\footnotetext{
* Burada adı geçen dört derginin atıf dizinleri kapsamındaki sadece 2009 yılındaki yayın sayısı 100'den fazladır.
} 
Türkiye adresli dergilerden biri (Turkish Journal of Chemistry) JCR sınıflamasında birden çok alanda yer almaktadır.* Söz konusu dergiye yönelik değerlendirmeler alanlardaki dergi listelerinin birleştirilmesi suretiyle gerçekleştirilmiştir. Türk Psikoloji Dergisi ve Türk Psikiyatri Dergisi JCR Social Sciences Edition altında yer alırken Türkiye adresli diğer sekiz dergi JCR Science Edition kapsamında bulunmaktadır. Bu nedenle her iki alana yönelik psikiyatri alanındaki toplam dergi sayıları birbirinden farklıdır (Bkz. Tablo II).

Tablo II. Türkiye Adresli Dergilerin İlgili Alanlardaki Etki Faktörü Sıralamaları

\begin{tabular}{lcccc}
\hline Dergi adı & $\begin{array}{c}\text { Etki } \\
\text { faktörü }\end{array}$ & Alan & $\begin{array}{c}\text { Alandaki } \\
\text { dergi } \\
\text { sayısı }\end{array}$ & $\begin{array}{c}\text { Etki } \\
\text { faktörü } \\
\text { sıralaması }\end{array}$ \\
\hline Journal of Sports Science and Medicine & 0,564 & Spor bilimleri & 71 & 55 \\
Klinik Psikofarmakoloji Bülteni & 0,197 & Psikiyatri & 101 & 98 \\
Mikrobiyoloji Bülteni & 0,301 & Mikrobiyoloji & 91 & 89 \\
Turkish Journal of Agriculture and Forestry & 0,479 & Agronomi & 49 & 39 \\
Turkish Journal of Chemistry & 0,727 & Kimya & 231 & 143 \\
Turkish Journal of Earth Sciences & 1,000 & Yer bilimleri & 144 & 93 \\
Turkish Journal of Pediatrics & 0,442 & Pediatri & 86 & 81 \\
Turkish Journal of Veterinary \& Animal Sciences & 0,280 & Veterinerlik & 135 & 109 \\
Türk Psikoloji Dergisi & 0,087 & Psikoloji & 101 & 101 \\
Türk Psikiyatri Dergisi & 0,486 & Psikiyatri & 86 & 79 \\
\hline
\end{tabular}

Türk Psikoloji Dergisi, Mikrobiyoloji Bülteni, Klinik Psikofarmakoloji Bülteni, Turkish Journal of Pediatrics ve Türk Psikiyatri Dergisi alanlarındaki dergiler arasında etki faktörü sıralamalarında oldukça gerilerde bulunmaktadır. Özellikle Türk Psikoloji Dergisi'nin etki faktörü sıralamasında psikoloji dergileri arasında son sırada yer alması düşündürücüdür. Diğer Türkiye adresli dergiler arasında ise Turkish Journal of Chemistry'nin etki faktörü açısından nispeten daha iyi konumda olduğu söylenebilir.

Araştırmamızda Türkiye adresli dergilerin etki faktörlerinin yıldan yıla nasıl bir değişim gösterdiği de incelenmektedir. Dergilerin tamamına yönelik değerlendirmeler yapılmasına karşın çalışmada SCI ve SSCI kapsamında en uzun süredir yer alan iki dergiye (Turkish Journal of Pediatrics ve Türk Psikoloji Dergisi) yönelik veriler tablo ve grafik halinde sunulmaktadır. Genel bir değerlendirme yapıldığında, Türkiye adresli dergilerin etki faktörlerinin bulundukları alanlardaki etki faktörü ortalama ve ortanca değerlerinden daha düşük olduğu saptanmıştır. Türkiye adresli dergilerdeki yayınların az sayıda atıf

* Turkish Journal of Chemistry hem çok disiplinli kimya alanında hem de kimya mühendisliği alanında yer alan bir dergidir. Çok disiplinli kimya alanında 127, kimya mühendisliği alanında 116 dergi bulunmasına karşın bu iki alan birleştirildiğinde çakışmalardan dolayı 231 dergi ile karşılaşılmaktadır. 
almasının doğal bir sonucu olarak da dergilerin etki faktörü değerleri düşüktür. Son yıllarda bazı Türkiye adresli dergilerin etki faktörü değerlerinde artış olduğu görülmekle birlikte, etki faktöründeki bu artış alandaki diğer tüm dergiler için geçerlidir.

Tablo III. Yıllara Göre Turkish Journal of Pediatrics'in Etki Faktörü

\begin{tabular}{cccccc}
\hline Yıl & $\begin{array}{c}\text { Etki } \\
\text { faktörü } \\
\text { (TJP) }\end{array}$ & $\begin{array}{c}\text { Etki faktörü } \\
\text { sıralaması } \\
\text { (TJP) }\end{array}$ & $\begin{array}{c}\text { Pediatri } \\
\text { alanındaki dergi } \\
\text { sayısı }\end{array}$ & $\begin{array}{c}\text { Pediatri dergilerinin } \\
\text { etki faktörlerinin } \\
\text { ortalaması }\end{array}$ & $\begin{array}{c}\text { Pediatri dergilerinin } \\
\text { etki faktörlerinin } \\
\text { ortancası }\end{array}$ \\
\hline 2008 & 0,442 & 81 & 86 & 1,676 & 1,384 \\
2007 & 0,408 & 74 & 78 & 1,525 & 1,277 \\
2006 & 0,387 & 71 & 74 & 1,500 & 1,162 \\
2005 & 0,236 & 71 & 73 & 1,347 & 1,114 \\
2004 & 0,312 & 66 & 70 & 1,261 & 1,105 \\
2003 & 0,184 & 68 & 68 & 1,236 & 1,053 \\
2002 & 0,340 & 65 & 68 & 1,195 & 0,971 \\
2001 & 0,122 & 67 & 69 & 1,140 & 0,906 \\
2000 & 0,089 & 70 & 71 & 1,039 & 0,823 \\
1999 & 0,173 & 67 & 72 & 0,985 & 0,799 \\
1998 & 0,120 & 67 & 71 & 0,894 & 0,681 \\
\hline
\end{tabular}

Pediatri dergileri içinde Turkish Journal of Pediatrics'in etki faktörü birçok derginin etki faktöründen oldukça düşüktür. Pediatri dergilerinin etki faktörü ortalamasının 1,676 ortancasının 1,384 olduğu 2008 yılında, Turkish Journal of Pediatrics'in etki faktörü 0,442 'dir. Pediatri alanındaki dergilerin etki faktörlerinin sürekli bir artış eğilimi gösterdiği, Turkish Journal of Pediatrics'in etki faktörü performansı açısından istikrarsız bir görünüme sahip olduğu anlaşılmaktadır (Bkz. Tablo III ve Şekil 3).

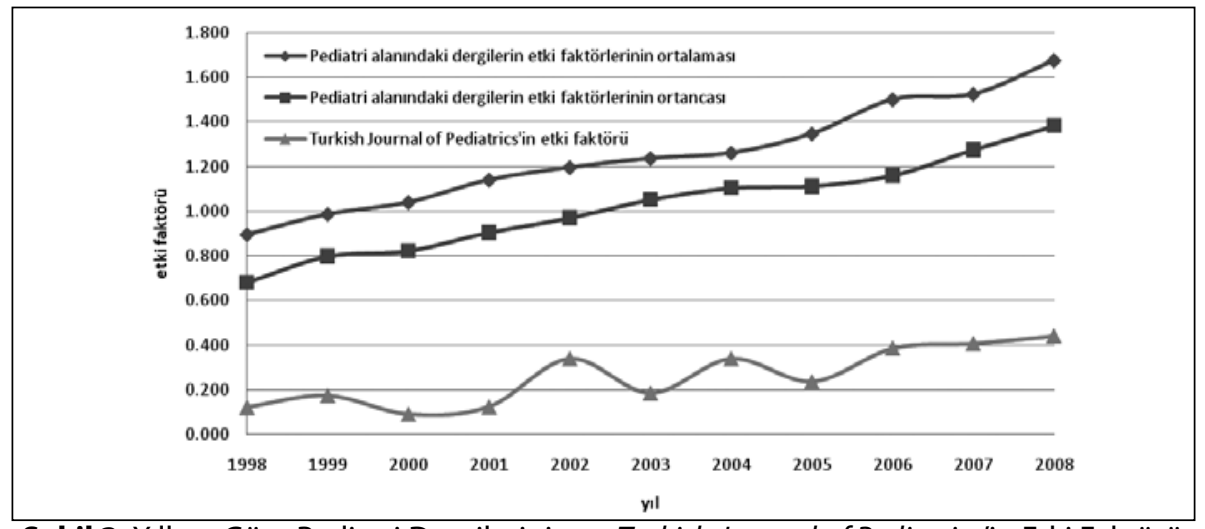

Şekil 3. Yıllara Göre Pediatri Dergilerinin ve Turkish Journal of Pediatrics'in Etki Faktörü 
Çalışmamız kapsamındaki en son $J C R$ verilerine göre psikoloji dergileri içinde Türk Psikoloji Dergisi etki faktörü bakımından en düşük değere sahip dergi konumundadır. 2008 yılı itibariyle psikoloji dergilerinin etki faktörü ortalaması 1,594 ortanca etki faktörü 0,898 iken; Türk Psikoloji Dergisi'nin etki faktörü 0,087'dir (Bkz Tablo IV).

Türk Psikoloji Dergisi'nin etki faktörüne dayalı olarak yapılan sıralamaya göre en olumlu göründüğü yıl ise 2002'dir. Söz konusu yıl hem derginin etki faktörü değeri şimdiye kadar gördüğü en yüksek değere $(0,278)$ ulaşmış, hem de etki faktörü sıralamasında 76. sırada yer alarak alanında 26 dergiyi geride bırakmıştır.

Tablo IV. Yıllara Göre Türk Psikoloji Dergisi'nin Etki Faktörü

\begin{tabular}{lccccc}
\hline Yıl & $\begin{array}{c}\text { Etki } \\
\text { faktörü } \\
\text { (TPD) }\end{array}$ & $\begin{array}{c}\text { Etki } \\
\text { faktörü } \\
\text { sıralaması } \\
\text { (TPD) }\end{array}$ & $\begin{array}{c}\text { Psikoloji } \\
\text { alanındaki } \\
\text { dergi sayısı }\end{array}$ & $\begin{array}{c}\text { Psikoloji } \\
\text { dergilerinin etki } \\
\text { faktörlerinin } \\
\text { ortalaması }\end{array}$ & $\begin{array}{c}\text { Psikoloji dergilerinin } \\
\text { etki faktörlerinin } \\
\text { ortancası }\end{array}$ \\
\hline 2008 & 0,087 & 101 & 101 & 1,594 & 0,898 \\
2007 & 0,154 & 98 & 102 & 1,340 & 0,748 \\
2006 & 0,103 & 98 & 99 & 1,489 & 0,722 \\
2005 & 0,222 & 87 & 101 & 1,292 & 0,650 \\
2004 & 0,125 & 96 & 100 & 1,251 & 0,704 \\
2003 & 0,100 & 100 & 101 & 1,212 & 0,633 \\
2002 & 0,278 & 76 & 102 & 1,078 & 0,703 \\
2001 & 0,222 & 84 & 100 & 0,984 & 0,513 \\
2000 & 0,214 & 89 & 105 & 0,948 & 0,476 \\
1999 & 0,067 & 101 & 107 & 0,940 & 0,446 \\
1998 & 0,074 & 107 & 109 & 0,997 & 0,491 \\
1997 & 0,074 & 102 & 108 & 0,841 & 0,417 \\
\hline
\end{tabular}

Yıl yıl diğer psikoloji dergileri ile karşılaştırıldığında Türk Psikoloji Dergisi'nin çok düşük etki faktörü değerine sahip bir dergi olduğu ortaya çıkmaktadır. Son yıllardaki etki faktörü ortalama ve ortanca değerlerinin yükselmesinin Türk Psikoloji Dergisi'ne pek fazla yansımadığı görülmektedir (Bkz. Tablo IV). 


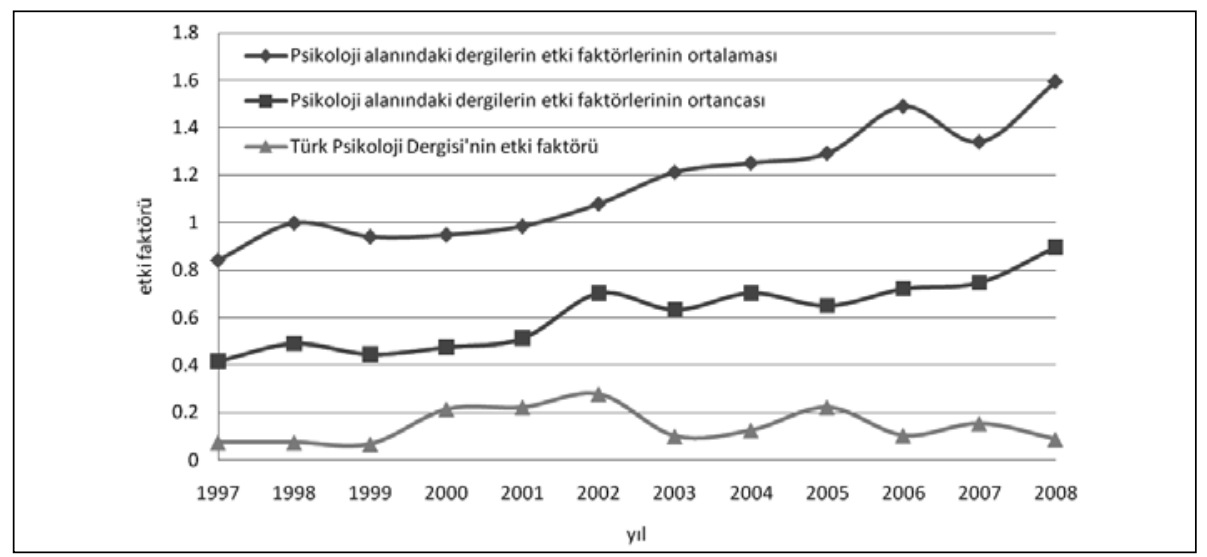

Şekil 4. Yıllara Göre Psikoloji Dergilerinin ve Türk Psikoloji Dergisi'nin Etki Faktörü

Türkiye Adresli Dergilerin Yerelliği

Çalışma kapsamındaki Türkiye adresli dergilerin yerel dergi olma özelliği gösterip göstermedikleri üç başlık altında ele alınmaktadır. Bu başlıklar yayınların yazarları, yayınların dili ve dergilerin yayın kurullarıdır. Türkiye adresli dergilerde yayın yapan kişilerin kimler olduğu, bu yayınların ne kadarının Türkçe olarak yayımlandığı ve bu dergilerde yer alan çalışmaları değerlendiren kişilerin ne kadarının ülke içinden olduğu konuları dergilerin yerelliği ile ile ilgili fikir sahibi olunmasını sağlayacaktır.

\section{Yazarlık}

Yazarlık kavramı uluslararasılık kavramı ile birlikte ele alındığında, yayınlarda bulunan adres bilgisi ya da yazarların milliyet bilgisinin ayrı ayrı düşünülmesi gerektiği bilinmektedir. Bu çalışmada yazarların milliyetleriyle değil, atıf dizinlerindeki yayınlara hangi ülkeden katkı yaptıklarıyla ilgilenilmektedir. Bu nedenle Türkiye adresli dergilerdeki Türkiye adresli araştırmacıların katkısına yönelik değerlendirmeler yapılmaktadır. Yurt dışında bulunup da Türkiye adresli dergilere katkı yapan araştırmacılar değerlendirmemizin dışında yer almaktadır.

Çalışmamızda Türkiye adresli dergilerde 12.455 yayın yapıldığı, bu yayınların 10.030 'unda en az bir yazarın Türkiye adresli araştırmacı olduğu saptanmıştır. Bu veriler Türkiye adresli dergilerdeki her beş yayından dördünde en az bir tane Türkiye'de görev yapan araştırmacının bulunduğunu göstermektedir. Bazı dergilerdeki tüm yayınlarda Türkiye adresli araştırmacıların olduğu görülmektedir. Aşağıdaki tabloda Türkiye adresli dergilerdeki Türkiye adresli araştırmacıların ne düzeyde yer aldığı bilgisi sunulmaktadır. Buna göre atıf dizinleri kapsamındaki Türkiye adresli dergilerin \%42'sinde, $\% 90$ 'nın üzerinde bir oranda en az bir yazarı Türkiye adresli olan yayınlar yer almaktadır (Bkz. TabloV).Türkiye adresli araştırmacı oranı nispeten düşük dergiler NeuroQuantology (\%3), 
Journal of Sports Science and Medicine (\%6), Experimental and Clinical Transplantation (\%14), Turkish Journal of Mathematics (\%38) ve Turkish Journal of Biology (\%39) adlı dergilerdir.

Tablo V. Türkiye Adresli Dergilerdeki Türkiye Adresli Yazar Oranları

\begin{tabular}{lcc}
\hline Türkiye adresli yazar oranı & Dergi sayısı & $\%$ \\
\hline$\% 91-100$ & 30 & 42 \\
$\% 81-90$ & 14 & 20 \\
$\% 71-80$ & 13 & 18 \\
$\% 61-70$ & 3 & 4 \\
$\% 51-60$ & 2 & 3 \\
$\% 41-50$ & 4 & 6 \\
$<\% 40$ & 5 & 7 \\
Toplam & 71 & 100 \\
\hline
\end{tabular}

Türkiye adresli dergilerdeki Türkiye adresli araştırmacı oranlarının yüksek olması bir bakıma doğal karşılanmakla birlikte, uluslararası olma iddiasındaki dergiler için üzerinde oldukça düşünülmesi gerekli bir konudur. Bu iddiaya sahip dergilerin başka ülkelerdeki araştırmacılar için çekim merkezi olma konusunda çalışmaları gerekmektedir.

Dil

Türkiye adresli dergilerde, Türkiye adresli yazarlar büyük oranda temsil edilmesine karşın, yayınların dile göre dağılımı incelendiğinde Türkçe yayın sayısının o denli yüksek olmadığı görülmektedir. Türkiye adresli dergilerdeki toplam 12.455 yayının 8237'si (\%66) İngilizce, 4188'i Türkçe'dir (\%34). İngilizce ve Türkçe dışında az sayıda olmakla birlikte Almanca (18), Fransızca (11) ve Yunanca (1) yayınlar da bulunmaktadır (Bkz. Şekil 5).

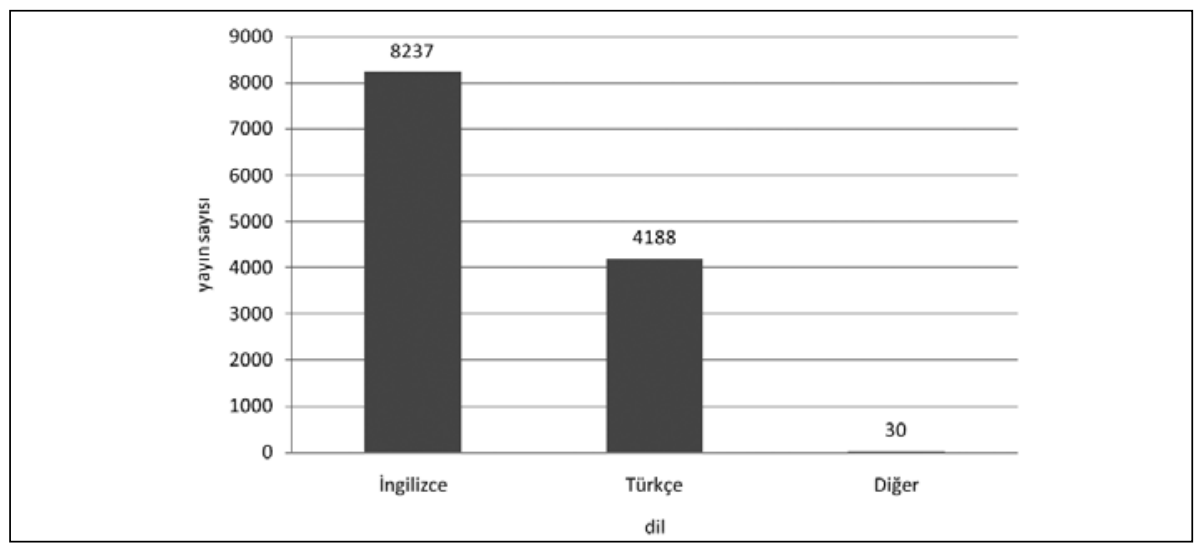

Şekil 5. Yayınların Dile Göre Dağılımı $(N=12.455)$ 
\%90'ın üzerinde Türkçe yayın içeren dergi sayısı 11 iken; Türkçe yayın sayısı \%40'dan az olan dergi sayısı 36'dır (Bkz. Tablo VI). Bu dergilerden 26'sında tek Türkçe yayın bile bulunmamaktadır. Bununla birlikte, yayınların üçte birinin dilinin Türkçe olması uluslararası platformdan daha fazla araştırmacının bu dergilere ilgi göstermesini (hem atıf yapılabilme açısından, hem de yayın gönderme açısından) bir ölçüde engellemektedir.

Tablo VI. Türkiye Adresli Dergilerdeki Türkçe Yayınların Oranı

\begin{tabular}{lcc}
\hline Türkçe yayın oranı & Dergi sayısı & $\%$ \\
\hline$\% 91-100$ & 11 & 15 \\
$\% 81-90$ & 6 & 8 \\
$\% 71-80$ & 6 & 8 \\
$\% 61-70$ & 5 & 7 \\
$\% 51-60$ & 3 & 4 \\
$\% 41-50$ & 4 & 6 \\
$<\% 40$ & 36 & 51 \\
Toplam & 71 & 99 \\
\hline
\end{tabular}

Not: Yuvarlama hatasından dolayı toplam yüzdesi \%100'e eşit değildir.

\section{Yayın Kurulu}

Uluslararası görünürlük açısından yayın kurulunda yabancı ülkelerden kişilerin bulunmasının önemli olduğu belirtilmektedir (Rey-Rocha ve Martín-Sempere, 2004, s. 112). Türkiye adresli dergilerde ise yayın kurulu üyelerinin büyük bir bölümünün Türkiye'de görev yapmakta olan araştırmacılardan oluştuğu saptanmıştır. Örneğin, dergilerin \%57'sinde Türkiye adresli hakem kurulu üyeleri \%71'in üzerinde bir oran ile temsil edilmektedir (Bkz. Tablo VII). Tamamı Türkiye'den olan kişilerin oluşturduğu yayın kurullarına sahip dergi sayısı ise 14'tür (Türkiye adresli tüm dergilerin \%21'i).

Tablo VII. Türkiye Adresli Dergilerdeki Türkiye Adresli Yayın Kurulu Üyelerinin Oranı

\begin{tabular}{lcc}
\hline Türkiye adresli yayın kurulu üyelerinin oranı & Dergi sayısı & $\%$ \\
\hline$\% 91-100$ & 17 & 25 \\
$\% 81-90$ & 5 & 7 \\
$\% 71-80$ & 17 & 25 \\
$\% 61-70$ & 8 & 12 \\
$\% 51-60$ & 6 & 9 \\
$\% 41-50$ & 5 & 7 \\
$<\% 40$ & 10 & 15 \\
Toplam & 68 & 100 \\
\hline
\end{tabular}


Az sayıdaki dergide Türkiye adresli yayın kurulu üyelerinin çok az bir bölümün Türkiye'den olduğu görülmektedir. Experimental and Clinical Transplantation adlı dergide Türkiye adresli yayın kurulu üyesi oranı \%5; Journal of Sports Science and Medicine adlı dergide \%16; Journal of International Advanced Otology adlı dergide \%19'dur. Bu dergilerin ortak özelliği yayınları arasında Türkçe çalışmalara hiç yer vermemiş olmaları ve Türkiye adresli yazar oranının da düşük olmasıdır (sırasıyla \%14; \%6 ve \%47).

\section{Sonuç ve Öneriler}

Bilimsel yayıncılıkta dergilerin önemli bir yeri bulunmaktadır. Dergilerin güncel bilginin paylaşıldığı ortamlar olması bilim çevrelerince dergilere verilen önem ile yakından ilişkilidir. Sağlam bilimsel yayın politikaları oluşturabilen uluslar geleceğin bilim dünyasının önderleri olacaktır. Bu bağlamda Türkiye'nin mevcut dergilerini mercek altına alarak değerlendirmesi gerekmektedir.

Bu çalışmada, Türkiye adresli dergilerin Türkiye'nin atıf dizinleri kapsamındaki yayın üretimine etkisi, etki faktörleri açısından alanlarındaki konumları, yayın dilleri gibi konular ele alınmıştır. Öte yandan Türkiye adresli dergilerde yayın kurullarındaki kişilerin ne kadarının Türkiye'deki araştırmacılardan oluştuğu ve dergilerdeki Türkiye adresli yazar katkısının ne düzeyde olduğu da değerlendirilmiştir. Türkiye adresli dergilerdeki yayınların yüzde 80'inden fazlasında en az bir yazarın Türkiye'de görev yaptığı, her üç yayından birinin dilinin Türkçe olduğu saptanmıştır. Bu durum beraberinde mevcut uygulamaların yeniden değerlendirilmesini de gündeme getirmektedir. Örneğin, adı uluslararası yayın teşvik programı olarak geçen program kapsamında atıf dizinleri kapsamında yayın yapan tüm Türkiye adresli dergilere yer verilmektedir. Öğretim üyeliğine atanma sürecindeki asgari koşullara uygunlukta en yüksek puanın verildiği koşullardan birisi atıf dizinleri kapsamındaki dergilerde yayımlanmış tam makale sahibi olunmasıdır. Son yıllardaki yerel nitelikli dergilerin atıf dizinleri kapsamına girmiş olması yukarıda sözü edilen uygulamaların ortaya çıkış felsefesi ile muhtemelen örtüşmemektedir.

Türkiye'deki bilimsel yayın faaliyetlerinin çoğunluğunun üniversitelerde yürütüldüğü bilindiğinden dergilere yönelik geliştirilecek politikalarda ve alınacak kararlarda bu durumun değerlendirilmesi gerekmektedir. Özellikle üniversitelerde yükselme ölçütleri arasında atıf dizinlerinde yayın sahibi olma zorunluluğu son yıllarda atıf dizinleri kapsamına giren dergi sayısındaki artış ile birlikte sorgulanması gereken bir konu haline gelmiştir. Günümüzdeki uygulamalar yayın sayısının artmasını teşvik edici niteliktedir. Oysa, ülkemizde bilimin gelişebilmesi için niteliğin artırılması konusunda yapılacak çalışmalara da gereksinim vardır.

Türkiye adresli dergilerin geçmiş dönemlere ilişkin göstermiş olduğu etki faktörü performansı, eğer herhangi bir politika değişikliği yapılmadığı takdirde, gelecekte söz konusu dergilerin alanlarında görünürlüğü düşük dergiler arasında yer alacağını 
ortaya koymaktadır. Dergilerde Türkiye'den bu denli yüksek katkının olmasının ve yayın kurullarında nispeten az sayıda yabancı bilim insanının bulunmasının dergilerin uluslararası camiada görünürlüğünü olumsuz etkilediği düşünülmektedir. Gelecekte yapılacak çalışmalarda bu durumun etkili olup olmadığı incelenmelidir.

\section{Kaynakça}

Al, U. (2008). Türkiye'nin bilimsel yayın politikası: Atıf dizinlerine dayalı bibliyometrik bir yaklaşım. Yayımlanmamış doktora tezi, Hacettepe Üniversitesi, Ankara.

Al, U. ve Coştur, R. (2007). Türk Psikoloji Dergisi'nin bibliyometrik profili. Türk Kütüphaneciliği, 21(2), 142-163.

Arıoğlu, E. ve Girgin, C. (2002). 1974-2001 döneminde ülkemizdeki bilimsel yayın performansının kısa değerlendirilmesi. 7 Mart 2011 tarihinde http://www.inovasyon.org/getfile.asp?file=E. ARIOGLU2.pdf adresinden erişildi.

Asan, A. (2006). Sci-Expanded, SSCl ve AHCI kapsamındaki Türk dergileri. O. Yılmaz (Yay. Haz.), Sağlık bilimlerinde süreli yayıncılık - 2006 içinde (ss. 86-92). Ankara: TÜBITAK.

Birinci, H. G. (2008). Turkish Journal of Chemistry'nin bibliyometrik analizi. Bilgi Dünyası, 9(2), 348369.

Buela-Casal, G., Perakakis, P., Taylor, M. ve Checa, P. (2006). Measuring internationality: Reflections and perspectives on academic journals. Scientometrics, 67(1), 45-65.

Cameron, B. D. (2005). Trends in the usage of ISI bibliometric data: Uses, abuses and implications. portal: Libraries and the Academy, 5(1), 105-125.

Dong, P., Moh, M. ve Mondry, A. (2005). The "impact factor" revisited. Biomedical Digital Libraries, 2(7). 7 Mart 2011 tarihinde http://www.bio-diglib.com/content/2/1/7 adresinden erişildi.

Garfield, E. (1994). The impact factor: ISI. Current Contents, 25, 3-7. 7 Mart 2011 tarihinde http:// scientific.thomson.com/free/essays/journalcitationreports/impactfactor/ adresinden erişildi.

Jacsó, P. (2009). Five-year impact factor data in the Journal Citation Reports. Online Information Review, 33(3), 603-614.

Katz, J. S. ve Hicks, D. (1997). How much is a collaboration worth? A calibrated bibliometric model. Scientometrics, 40(3), 541-554.

Marušić, A. ve Marušić, M. (1999). Small scientific journals from small countries: breaking from a vicious circle of inadequacy. Croatian Medical Journal, 40(4), 508-514.

Moed, H.F. (2006). Bibliometric rankings of world universities. Centre for Science and Technology Studies Report 2006-01. 7 Mart 2011 tarihinde http://www.cwts.nl/hm/bibl_rnk_wrld_univ_ full.pdf adresinden erişildi.

Najman, J. M. ve Hewitt, B. (2003). The validity of publication and citation counts for sociology and other selected disciplines. Journal of Sociology, 39(1), 62-80.

Orbay, M., Karamustafaoğlu, O. ve Öner, F. (2007). What does Hirsch index evolution explain us? A case study: Turkish Journal of Chemistry. Biblios, 8(27), 1-5. 7 Mart 2011 tarihinde http://arxiv. org/ftp/arxiv/papers/0704/0704.1602.pdf adresinden erişildi. 
Rey-Rocha, J. R. ve Martín-Sempere, M. J. (2004). Patterns of the foreign contributions in some domestic vs. international journals on Earth Sciences. Scientometrics, 59(1), 95-115.

Rousseau, R. (1988). Citation distribution of pure mathematics journals. L. Egghe ve R. Rousseau (Yay. Haz.), Informetrics 87/88: Select proceedings of the first international conference on bibliometrics and theoretical aspects of information retrieval, Diepenbeek, Belgium, 25-28 August 1987 içinde. (ss. 249-262). Amsterdam: Elsevier.

Saha, S., Saint, S. ve Christakis, D. A. (2003). Impact factor: a valid measure of journal quality? Journal of the Medical Library Association, 91(1), 42-46.

Semenzato, G., Rizzato, G. ve Agostini, C. (2004). Impact factor as measure of scientific quality. American Journal of Respiratory and Critical Care Medicine, 169, 1070-1071.

Thomson Reuters. (2009). Content expansion. 22 Aralık 2009 tarihinde http://isiwebofknowledge. com/products_tools/multidisciplinary/webofscience/contentexp/ adresinden erişildi.

Thomson Reuters. (2010). Content expansion. 25 Temmuz 2010 tarihinde http://wokinfo.com/ products_tools/multidisciplinary/webofscience/contentexp/adresinden erişildi.

Tijssen, R. J. W. (2007). Africa's contribution to the worldwide research literature: New analytical perspectives, trends, and performance indicators. Scientometrics, 71(2), 303-327.

Ulusal Akademik Ağ ve Bilgi Merkezi (2009). ISI Web of Science (WoS)'da indekslenen Türkçe dergiler. 15 Aralık 2009 tarihinde http://www.ulakbim.gov.tr/cabim/vt/uvt/isi_dergiler.uhtml adresinden erişildi.

Uzun, A. (2004). Assessing internationality of scholarly journals through foreign authorship patterns: the case of major journals in information science, and scientometrics. Scientometrics, $61(3), 457-465$.

Van Leeuwen, T. N. ve Moed, H. F. (2002). Development and application of journal impact measures in the Dutch science system. Scientometrics, 53(2), 249-266.

Yılmaz, B. (2002). Konu, ülke orijini ve dil dağılımı açısından atıf dizinleri (SCI ve SSCI). Bilim ve Ütopya, 94, 47-51.

Zitt, M. ve Bassecoulard, E. (1998). Internationalization of scientific journals: A measurement based on publication and citation scope. Scientometrics, 41(1-2), 255-271. 